Original Research Article

\title{
Medical student's perception on teaching-learning methods of pharmacology in a medical college
}

\author{
Lakshmi Sravanthi Mukku, Jagadeesh Alla*, Ramya Rachamanti
}

Department of Pharmacology,

NRI Academy of Medical

Sciences, Guntur, Andhra

Pradesh, India

Received: 19 January 2018

Received: 01 February 2018

Accepted: 05 March 2018

*Correspondence to:

Dr. Jagadeesh Alla,

Email: jagannri@gmail.com

Copyright: (C) the author(s), publisher and licensee Medip Academy. This is an openaccess article distributed under the terms of the Creative Commons Attribution NonCommercial License, which permits unrestricted noncommercial use, distribution, and reproduction in any medium, provided the original work is properly cited.

\begin{abstract}
Background: To know the Medical student's perception on teaching and learning methods of pharmacology in a medical college attached to tertiary care hospital.

Methods: This is a questionnaire based study conducted in a medical college. A pre-validated, pre-designed questionnaire containing 22 points was given to $5^{\text {th }}$ semester students to know their perception on teaching and learning methods.

Results: Analysis was done on 150 medical students of a tertiary care hospital. Among them, $80 \%$ wanted the faculty members to make more utilization of Audio-Visual aids for effective learning. $78.67 \%$ students wanted to include case based learning in the curriculum and $86.67 \%$ wanted more of the clinical pharmacology to be introduced. A $28 \%$ wanted MCQs (Multiple Choice Questions) to be included in the assessment of academic performance. A $13.33 \%$ felt that the ideal teaching method for learning pharmacology was didactic lectures. A $65 \%$ thought ideal teaching/learning media for pharmacology was the combination of LCD (Liquid Crystal display) projector and blackboard.

Conclusions: The study revealed the ideal teaching and learning methods in pharmacology for the betterment of students.
\end{abstract}

Keywords: Learning, Medical students, Methods, Pharmacology, Teaching

\section{INTRODUCTION}

Institutions of higher education like medical colleges are one of the most essential elements of modern society. It is important that educators provide the high quality teaching and learning environment possible for the students. ${ }^{1}$

Students usually follow deep or surface approach while learning. The deep approach involves an intention to gain personal understanding, with corresponding strategies to gain meaning from the learning task. The surface approach is an intention to avoid failure facilitating the memorisation of facts without meaning. ${ }^{2}$ Fostering deeper approaches to learning in students with surface learning preferences is a complex process, and the factors which encourage such development need to be studied. As a part of deep approach students now prefer to utilize media like internet as per their comfort and completeness of concept.

Learning is considered as an accumulation of individual pieces of knowledge. ${ }^{3}$ The learning outcome is largely dependent on the student's pre-existing beliefs about knowledge and learning. Different students perceiving the same learning environments vary differently due to varying beliefs. Proper learning includes affective as well as cognitive components. ${ }^{4}$ Furthermore, it is important to recognise the way in which the teaching context influences 
learning. ${ }^{5}$ The present study was carried out with an objective to know the perception of students on learning and teaching methodologies in a tertiary care hospital attached to medical college. Based on the results obtained in this study, modifications will be implemented in teaching strategies accordingly for the benefit of students.

\section{METHODS}

This is a questionnaire based study done at a medical college attached to a tertiary care hospital, Guntur. After taking informed consent from students, their perception on learning and teaching methods was known in the following pattern:

Part A: 6 definitive questions with options Yes and No

Part B: 3-point likert scale-based questions with options agree, disagree and neutral ${ }^{6}$

Part C: 2 MCQ based questions.

\section{Inclusion criteria}

- As per our feasibility, students of $2^{\text {nd }}$ year MBBS studying at NRI medical college were only included.

- $\quad 1^{\text {st }}$ and final year students, house surgeons and post graduates were excluded.

\section{Sample size}

154 Medical students were there in $2^{\text {nd }}$ year MBBS at NRI medical college. Questionnaire was given to them and they were asked to fill up in the lecture gallery during their free time. Informed consent was mentioned at the top of the questionnaire. Those who are willing to participate were only included in the study. 154 students have signed the informed consent form. 150 complete forms were analyzed.4 Incomplete forms were excluded.

\section{Statistical analysis}

The data were analysed using MS office Excel and expressed as percentage.

\section{RESULTS}

The data of 150 medical students were analysed by MS office excel. Among the participants 102 students were Female (Figure 1).

Among the students who participated in the study majority $(63 \%)$ of the students parents were from non medical background.

Part-A: Among the students participated in the study $87 \%$ expressed opinion that student seminars should be introduced in the curriculum. $80 \%$ of the students expressed the opinion that group discussions should be introduced. Majority of the students expressed the curriculum should be based on more clinical pharmacology (Table 1).

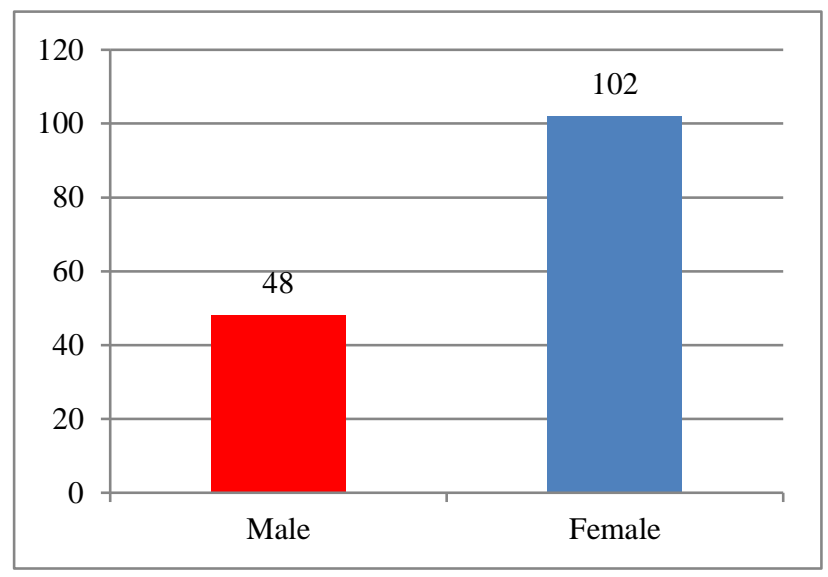

Figure 1: Gender wise distribution of participants.

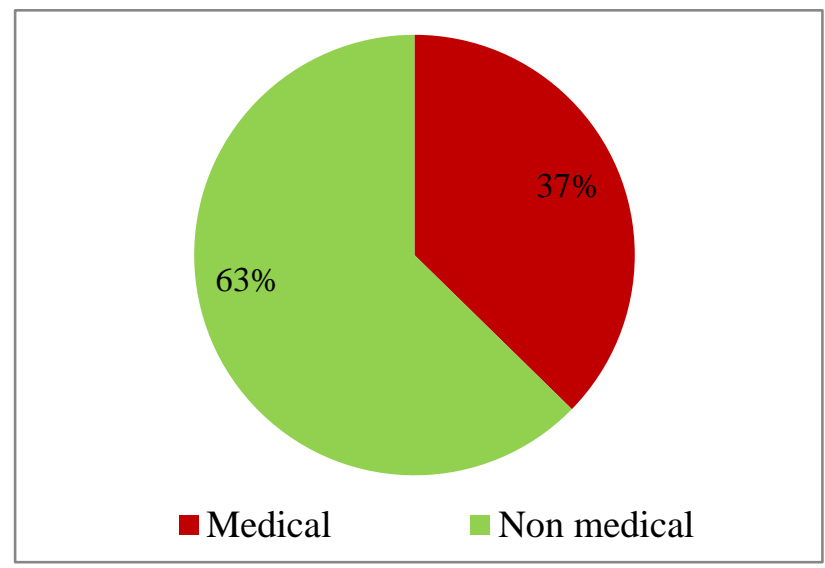

Figure 2: Distribution of students parents background.

Table 1: Questionnaire.

\begin{tabular}{|lll|}
\hline $\begin{array}{l}\text { Opinion about changes } \\
\text { recommended }\end{array}$ & $\begin{array}{l}\text { Yes } \\
(\%)\end{array}$ & $\begin{array}{l}\text { No } \\
(\%)\end{array}$ \\
\hline $\begin{array}{l}\text { Need to Increase the number of } \\
\text { lectures }\end{array}$ & 81.34 & 18.66 \\
\hline Make more use of audio-visual aids & 80.00 & 20.00 \\
\hline Introduce student seminars & 86.67 & 13.33 \\
\hline Introduce Case based learning & 78.67 & 21.33 \\
\hline $\begin{array}{l}\text { Introduce more clinical pharmacology } \\
\text { (Pharmacovigilance) }\end{array}$ & 86.67 & 13.33 \\
\hline Introduce group discussions & 80.00 & 20.00 \\
\hline
\end{tabular}

Part-B: Among the participants 80 students didn't pick pharmacology as their favourite $2^{\text {nd }}$ year subject. Only 4 students agreed that Pharmacology will help immensely in choosing drugs rationally for their future clinical practice. 50 students agreed that calculation of Pharmacokinetic parameters are relevant and helped them in better understanding of General Pharmacology. 80 students agreed that charts will help in better understanding of the mechanism of action of drugs (Table 2). 
Table 2: Likert point scale questionnaire.

\begin{tabular}{|c|c|c|c|}
\hline \multirow{2}{*}{ Item } & \multicolumn{2}{|c|}{ (No of students) } & \multirow[b]{2}{*}{ Agree } \\
\hline & Disagree & Neutral & \\
\hline I find pharmacology lecturers interesting and stimulating & 70 & 20 & 60 \\
\hline Pharmacology is my favourite subject in $2^{\text {nd }}$ year of MBBS & 80 & 20 & 50 \\
\hline $\begin{array}{l}\text { I would like Pharmacology to be more closely integrated with the } \\
\text { clinical sciences and would like real cases in hospital to be used } \\
\text { during problems stimulated learning (PSL) }\end{array}$ & 30 & 110 & 10 \\
\hline $\begin{array}{l}\text { The subject has helped me to develop my problem solving and } \\
\text { logical-reasoning skills }\end{array}$ & 60 & 60 & 30 \\
\hline $\begin{array}{l}\text { The subject will help me immensely in choosing drugs rationally } \\
\text { in my future clinical practice }\end{array}$ & 20 & 126 & 4 \\
\hline I would like MCQs to be included in the assessment & 50 & 52 & 48 \\
\hline $\begin{array}{l}\text { Discussion charts help in better understanding of mechanism of } \\
\text { action of drugs }\end{array}$ & 20 & 50 & 80 \\
\hline $\begin{array}{l}\text { Calculation of pharmacokinetic parameters (e.g. Vd, } \mathrm{t}_{1 / 2} \text {, } \\
\text { Therapeutic index) is relevant and helps in better understanding of } \\
\text { general pharmacology }\end{array}$ & 20 & 80 & 50 \\
\hline
\end{tabular}

Part C: The results were analyzed by giving 2 MCQ based questions. Among the participants majority of the students preferred tutorials, group discussions and seminar as their best choice for teaching method (Figure 3).

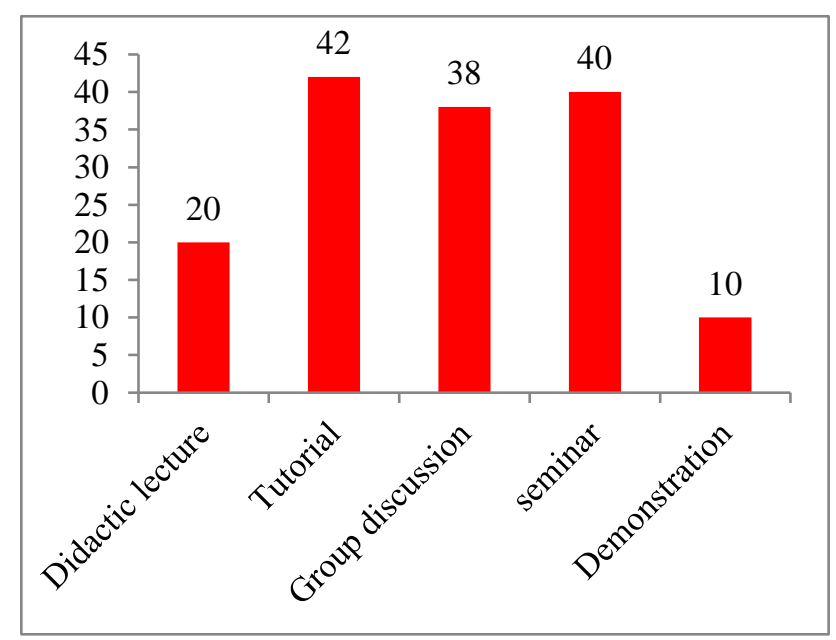

Figure 3: Students choice of best teaching method.

Among the participants in the study 98 students expressed the opinion that power point combined with black board teaching as their ideal learning media. Only seven students felt black board teaching as their ideal teaching learning media (Figure 4).

\section{DISCUSSION}

Need for reviewing the teaching program regularly in the methodologies of imparting medical knowledge about drugs and therapies is a must. This study was conducted to determine the perception and feedback of teaching/learning pharmacology using a pre-validated questionnaire among $2^{\text {nd }}$ year medical students.

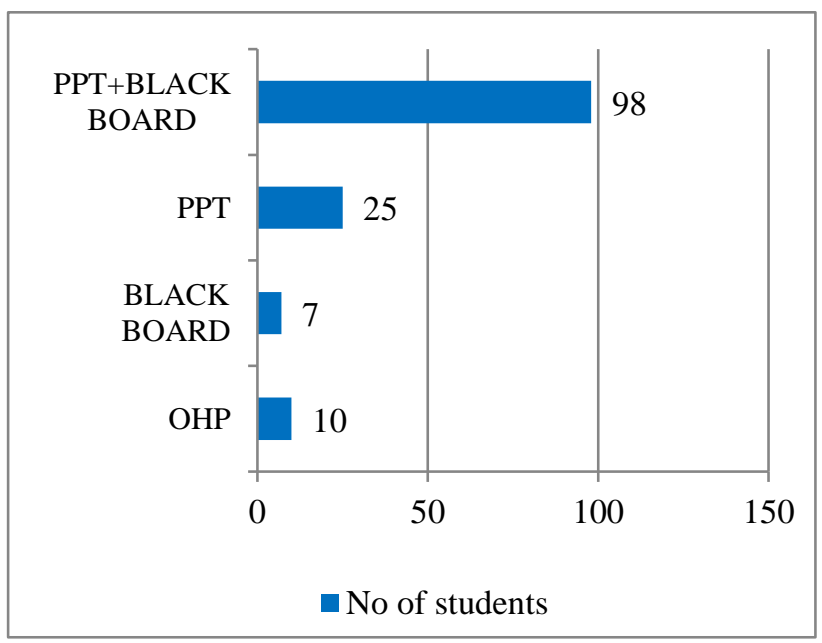

Figure 4: Ideal teaching learning media.

A $78.67 \%$ students need case based learning (Table 1) to be introduced into the curriculum as against $98 \%$ reported in the study done by Manjunath et al and $73 \%$ as reported by Jai Krishna et al. ${ }^{7,8}$ About $80 \%$ (Table 1) students in our study wanted group discussions to be introduced which was more than the findings of Jai Krishna et al who reported only $31 \% .^{8}$

In the current study, it was observed that $75 \%$ students agreed that pharmacology is more closely related to clinical 
sciences and real cases from hospitals should be used during problem based learning .This is in agreement with the findings of study conducted in New Delhi where $80 \%$ students were in favour of the bedside teaching of clinical pharmacology. ${ }^{9}$ Students should be taken to wards for discussion of treatment strategies of admitted cases. Need for integration of pharmacology with clinical subjects was also supported by several accreditation organizations in medical education like General Medical Council, the Association of American Medical Colleges and the American Medical Association as per sekhri K. ${ }^{10}$ This integration will provide students with the opportunity to become familiar with various diseases and the important role of pharmacology. ${ }^{11}$ For this reason, many medical schools have integrated pharmacology during clinical years. $^{12}$

In the current study, 98 students (Figure 3) agreed that recent advances need to be included in the curriculum which is similar to findings by Jai Krishna et al. ${ }^{7}$ There is a stigma attached among medicos regarding the study of pharmacology as per walley $\mathrm{T}$ and the students' interests were more inclined towards clinical career with earning far better than pharmacological career as reported by Zgheib et al. ${ }^{13,14}$

Limitation of present study: This study was done among only $2^{\text {nd }}$ year medical students in a single tertiary care centre. More multicentre studies need to be carried out among the medical students to draw accurate conclusions.

\section{ACKNOWLEDGEMENTS}

Authors would like to thank medical students of NRI medical college for their valuable participation.

Funding: No funding sources

Conflict of interest: None declared

Ethical approval: The study was approved by the Institutional Ethics Committee

\section{REFERENCES}

1. Atkins MS, Hoagwood KE, Kutash K, Seidman E. Toward the Integration of Education and Mental Health in Schools. Administration and policy in mental health. 2010;37(1-2):40-7.

2. Ramsden P. Learning to teach in higher education. $\mathbf{J}$ Studies in Higher Education. 1993;18(1).

3. Angle HL, Perry JL. An empirical assessment of organizational commitment and organizational effectiveness. Administrative science quarterly. 1981:1-4.

4. Wubbels T, Brekelmans M. Two decades of research on teacher-student relationships in class. Inter $\mathrm{J}$ Edu Res. 2005;43(1-2):6-24.

5. Baird and Northfield. Learning from the PEEL experience. Melbourne, Australia: Monash University. Creative Education. 2013;4(2).

6. Wuensch KL. What is a likert scale? and how do you pronounce'likert?'. East Carolina University. 2005;4.

7. Manjunath SM, Nagesh Raju G, Srinivas TR, Someswara GM. A study on the evaluation of medical students' perception and feedback of teachinglearning of pharmacology in a medical college IAIM. 2015;2(9):102-10

8. Jai K, Abhishek S, Shwetank G, Aakansha G, Priyamvada S, Mirza URB, et al. Students' current perceptions and feedback on teaching and learning Pharmacology from an evolving medical school. IAIM. 2015;2(7):99-104.

9. Kela AK, Mehta VL. Impact of inclusion of clinical projects in undergraduate teaching. Indian $\mathbf{J}$ Pharmacol. 1993;25:249-50.

10. Sekhri K. Teaching methodologies in pharmacology: a survey of students' perceptions and experiences. J Educ Ethics Dent. 2012;2(1):40.

11. Han WH, Maxwell SR. Are medical students adequately trained to prescribe at the point of graduation? Views of first year foundation doctors. Scottish Med J. 2006;51(4):27-32.

12. Dunaway GA, Faingold CL. Development and implementation of a multidisciplinary sophomore medical curriculum: Integration of pharmacology with basic and clinical sciences. Pharmacologist. 2001;43:83-90.

13. Walley T, Bligh J, Orme M, Breckenridge A. Clinical pharmacology and therapeutics in undergraduate medical education in the UK: The future. Br J Clin Pharmacol. 1994;37:137-43.

14. Zgheib NK, Simaan JA, Sabra R. Using team-based learning to teach pharmacology to second year medical students improves student performance. Medic Teach. 2010;32:130-35.

Cite this article as: Mukku LS, Alla J, Rachamanti R. Medical student's perception on teaching-learning methods of pharmacology in a medical college. Int $\mathbf{J}$ Basic Clin Pharmacol 2018;7:665-8. 